\title{
PERAN KEPUASAN DALAM MEMEDIASI PENGARUH KEPERCAYAAN TERHADAP NIAT BELI ULANG PADA GO-FOOD DI FEB UNUD
}

\author{
Bagus Dwipayana ${ }^{1}$ \\ Eka Sulistyawati \\ ${ }^{1,2}$ Fakultas Ekonomi dan Bisnis Universitas Udayana, Bali, Indonesia \\ Email: dwipayanabagusworld@gmail.com
}

\begin{abstract}
ABSTRAK
Niat untuk menggunakan kembali barang atau jasa merupakan cerminan bahwa jasa yang ditawarkan perusahaan berkualitas sehingga pelanggan merasa puas. Mengacu teori perilaku konsumen, penelitian ini bertujuan untuk mengetahui pengaruh kepercayaan dan kepuasan terhadap niat beli ulang. Penelitian ini dilakukan pada 1873 mahasiswa non-reguler Fakultas Ekonomi dan Bisnis Universitas Udayana, sampel ditentukan menggunakan rumus slovin dan didapatkan sampel sejumlah 95 orang mahasiswa non-reguler. Pengumpulan data menggunakan kuesioner. Teknik analisis yang digunakan adalah analisis faktor dan path analysis untuk menguji pengaruh kepercayaan dan kepuasan terhadap niat beli ulang. Hasil pengujian hipotesis pertama menunjukan kepercayaan berpengaruh positif terhadap niat beli ulang. Hasil hipotesis kedua menunjukan kepuasan berpengaruh positif terhadap kepercayaan. Hasil hipotesis ketiga menunjukan kepuasan berpengaruh positif terhadap niat beli ulang, dan yang terakhir hipotesis keempat menunjukan bahwa kepuasan memediasi secara positif hubungan antara kepercayaan terhadap niat beli ulang. Tingginya tingkat kepercayaan dan kepuasan konsumen akan meningkatkan peluang niat membeli ulang dari konsumen.
\end{abstract}

Kata kunci : perilaku konsumen, kepercayaan, kepuasan, niat beli ulang

\begin{abstract}
The intention to reuse goods or services is a reflection of the services that quality companies offer so that customers feel satisfied. Referring to the theory of consumer behavior, this study aims to determine the effect of trust and satisfaction with the intention to buy back. The study was conducted in 1873 students of the Faculty of Economics and Business Udayana University, a sample of 95 students was obtained. Analytical technique used is factor analysis and path analysis. The results of testing the first hypothesis shows the positive effect of trust on the intention to buy back. Results of the second hypothesis show satisfaction positive effect on trust. The results of the third hypothesis show satisfaction positive effect on the intention of buy back, and the last fourth hypothesis shows that satisfaction mediates positively the relationship between beliefs on repurchase intentions. The high level of trust and consumer satisfaction will increase the chances of rebuying intention from consumers.
\end{abstract}

Keyword : consumer behavior, trust, satisfaction, re-purchase intention 
Bagus Dwipayana, Peran Kepuasaan Dalam Memediasi Pengaruh...

\section{PENDAHULUAN}

Pengaruh internet yang lambat laun semakin berkembang pada gaya hidup manusia di hari-harinya ternyata bisa memberi pengaruh prilaku serta kehidupan rakyat. Ini sebenarnya bisa ditinjau dari makin besarnya total pemakai internet di Indonesia. Memang hal ini tak mengejutkan karena memang saat ini telepon seluler (ponsel) menjadi salah satu media favorit masyarakat dalam mengakses internet, ini dikarenakan ponsel lebih mudah dibawa dan fungsi ponsel-ponsel saat ini yang semakin canggih sehingga bisa memudahkan pengguna dalam mengakses informasi baik melalui media sosial dan web, bermain game online maupun dalam melakukan bisnis seperti jual beli online. Belanja online atau biasa disebut $e$ commerce merupakan salah satu cara bagi para pemasar untuk memasarkan produknya. Oleh sebab itu banyak perusahaan-perusahaan mulai menggunakan $e$ commerce dalam memasarkan produknya hal ini dikarenakan e-commerce merupakan salah satu cara terbaik dalam meningkatkan jumlah transaksi bisnis ke konsumen (Kaur dan Quareshi, 2015).

Berbeda dengan belanja konvensional, belanja online memiliki sifat unik seperti ketidakpastian, ketidakamanan, dan kontrol yang kurang terhadap pihakpihak yang terlibat. Sebagai contoh, seringkali dalam belanja online, konsumen diminta untuk mengisi data pribadi serta informasi keuangan dan juga sering kali produk yang diterima konsumen mengalami kerusakan saat pengiriman. Jadi, pada dasarnya selalu ada keraguan dalam benak pelanggan apakah mereka akan menerima layanan yang sebanding dengan apa yang diterangkan di internet (Mcknight et al., 2002). E-lectronic commerce (e-commerce) seringkali di artikan 
sebagai menjual barang secara online. Akan tetapi sebenarnya jual beli online tidak hanya menjual barang saja secara online melainkan bisa juga dengan menjual jasa melalui internet. Dengan semakin maraknya penggunaan internet seperti yang telah dijelaskan di atas membuat para pelaku bisnis mengambil peluang tersebut salah satunya adalah dengan cara menggabungkan antara jasa transportasi dan teknologi internet. Sebenarnya hal ini tidak terlalu berbeda dengan bisnis jasa pada umumnya, cuma yang membedakannya disini ialah dalam penggunaanya dibutuhkan koneksi internet. Meninjau kesempatan berbisnis menggunakan media internet yang amat menguntungkan, sehingga banyak pebisnis mensinergikan antara akomodasi dengan internet. Seperti satu pebisnis yang mengambil manfaat dari teknologi internet dengan hanya menggunakan mobile-phone untuk wadah pendukung bisnisnya merupakan jasa ojek dengan basis aplikasi online. Ojek online adalah satu dari sekian pemecahan masalah yang disediakan oleh pelaku bisnis dalam mengatasi masalah rakyat tentang kemacetan yang terjadi di beberapa kota di Indonesia. Melalui pembukaan aplikasi internet yang dipakai untuk penghubung transaksi pemakaian ojek, bisa membuat mudah kita untuk mendapatkan pelayanan jasa yang disediakan.

PT. GO-JEK Indonesia adalah salah satu start-up serta satu dari sekian organisasi bergerak dalam bidang jasa transportasi dengan basis aplikasi internet. Usaha rintisan digital (startup) kini mulai berkembang pesat seiring dengan perkembangan bisnis online. Definisi (startup) sendiri lebih merujuk kepada perusahaan yang belum lama beroperasi. Perusahaan-perusahaan ini sebagian besar merupakan perusahaan yang baru didirikan dan berada dalam fase 
Bagus Dwipayana, Peran Kepuasaan Dalam Memediasi Pengaruh...

pengembangan dan penelitian untuk menemukan pasar yang tepat (https://id.wikipedia.org/wiki/Perusahaan_rintisan/).

GO-JEK sendiri adalah sebuah perusahaan teknologi berjiwa sosial yang bertujuan untuk meningkatkan kesejahteraan pekerja di berbagai sektor informal di Indonesia. GO-JEK merupakan perusahaan yang menyediakan jasa transportasi berbasis online untuk mengantar penumpang, makanan dan lain sebagainya. Kegiatan GO-JEK bertumpu pada tiga nilai pokok yaitu: kecepatan, inovasi, dan dampak sosial. Untuk saat ini GO-JEK telah beroperasi di 10 kota besar di Indonesia yaitu Jakarta, Bandung, Bali, Surabaya, Makassar, Yogyakarta, Medan, Semarang, Palembang, dan Balikpapan (https://www.go-jek.com/). GO-JEK sendiri saat ini telah menyediakan berbagai layanan untuk para pelanggannya antara lain, GO-RIDE, GO-CAR GO-FOOD, GO-SEND, GO-MART, GO-BOX, GO-MASSAGE, GO-CLEAN, GO-GLAM, GO-TIX, GO-BUSWAY, dan GOPAY yang semuanya bergerak dibidang pelayanan jasa elektronik (e-service) (https://www.go-jek.com/). Berdasarkan lembaga riset global, Growth for Knowlegde (GfK) Indonesia, mengeluarkan data yang berkaitan tentang aplikasi transportasi dengan basis online manakah yang disukai di Indonesia. Media Director Consumer Choises GFK Indonesia, Robin Muliady memberikan pernyataan, jasa transportasi dengan basis online yang paling sering digunakan merupakan GO-JEK.

Hasil prasurvei pada mahasiswa FEB unud sebanyak 10 orang, dengan 8 dari 10 mahasiswa menyatakan bahwa mereka lebih sering menggukan GOFOOD dibanding layanan GO-JEK lainnya dan dua orang sisanya sering 
menggunakan Go-Ride. Alasan peneliti untuk memilih mahasiswa FEB unud sebagai subjek penelitian ini adalah karena peneliti ingin mengetahui seberapa familiar GO-FOOD ini di kalangan mahasiswa. Dari delapan mahasiswa yang telah diwawancarai menyatakan bahwa GO-FOOD merupakan salah satu layanan yang terbilang sangat unik karena menggunakan internet sebagai basisnya. Selain itu, layanan GO-FOOD saat ini telah bekerjasama dengan lebih dari 37.000 outlet atau rumah makan di seluruh Indonesia dan tidak menutup kemungkinan akan bertambah seiring waktu. Walaupun kebanyakan para pelanggan merasa sangat terbantu dengan adanya layanan GO-FOOD ini tetapi ada saja yang merasa sedikit dikecewakan contohnya seperti makanan yang dipesan tiba-tiba di cancel booking si driver GO-JEK dengan alasan harga makanan yang terlalu tinggi dan juga terkadang terjadi perbedaan antara makanan yang dipesan dan yang diantar, tetapi mereka tetap percaya terhadap layanan ini dan tetap saja mereka memesan makanan lewat layanan ini. Jadi, pada dasarnya kepercayaan merupakan salah satu alasan kenapa konsumen ingin melakukan pembelian ulang

Kepercayaan dan kepuasan merupakan faktor kunci dalam membangun niat membeli ulang konsumen. Hal ini dapat dipertegas oleh hasil penelitian yang dilakukan oleh Fang et al. (2011) yang menyatakan bahwa niat membeli ulang paling dominan dipengaruhi oleh kepuasan. Masih menurut penelitian yang sama juga menunjukkan bahwa kepercayaan pula memiliki pengaruh yang signifikan terhadap niat membeli ulang, walaupun pengaruhnya cenderung lemah. Akan tetapi menurut penelitian yang dilakukan oleh Chiu et al. (2009) menyatakan bahwa kepercayaan memiliki pengaruh yang positif signifikan terhadap niat beli ulang. 
Bagus Dwipayana, Peran Kepuasaan Dalam Memediasi Pengaruh...

Menurut Muslikhah dkk. (2015) pada penelitiannya menunjukkan bahwa niat membeli ulang dipengaruhi oleh dua variabel yaitu kepercayaan merk dan kepuasan. Jadi, secara garis besar dapat disimpulkan jika konsumen percaya ataupun puas terhadap suatu produk maka konsumen tersebut akan cenderung mempunyai niat untuk membeli kembali.

Berdasarkan fenomena dan juga riset gap yang telah dipaparkan, tujuan utama dari penelitian ini adalah untuk menguji dan menganalisis bagaimana peran kepuasan dalam memediasi pengaruh kepercayaan terhadap niat beli ulang pada GO-FOOD yang dimana studi ini dilakukan pada Mahasiswa Fakultas Ekonomi dan Bisnis Universitas Udayana.

Menurut Kotler (2008:182) tujuan pemasaran merupakan memberikan serta memberi kepuasan pada kebutuhan dan rasa ingin konsumen yang menjadi target. Bagian ilmu perilaku konsumen mempelajari bagaimanakah seseorang, kelompok dan perusahaan memilih, membeli, memakai dan memanfaatkan barang, jasa, ide ataupun pengalaman untuk memberi kepuasan pada kebutuhan juga hasrat mereka. Perilaku konsumen adalah suatu ilmu yang mempelajari bagaimana perilaku seorang individu atau kelompok dalam membeli, menggunakan atau memanfaatkan suatu produk atau jasa untuk memenuhi baik kebutuhan maupun keinginan mereka. Kepercayaan dibutuhkan oleh pengguna teknologi informasi dalam rangka meningkatkan kinerja individu dalam melakukan kegiatan organisasi atau perusahaan. Menurut McKnight et al. (2002), kepercayaan didefinisikan sebagai keyakinan yang memungkinkan individu dengan sukarela untuk menjadi pelanggan terhadap penyedia layanan e-commerce setelah 
mempertimbangkan karakteristik dari penyedia layanan e-commerce. Kepercayaan dalam berbelanja online melalui media sosial merupakan faktor penentu yang penting dalam menentukan keberhasilan atau kegagalan dari setiap kegiatan penjual di pasar khususnya pada bisnis online. Kepercayaan merupakan keyakinan yang membuat seseorang dengan sukarela menerima resiko dari tindakan pihak lain dengan didasari harapan bahwa pihak lain tersebut akan melakukan tindakan yang penting untuk individu yang mempercayainya.

Kotler dan Keller (2009:200) memberi definisi kepuasan konsumen diibaratkan perasaan konsumen, baik itu dalam bentuk kesenangan ataupun kekecewaan yang ditimbulkan dari membuat perbandingan tampak dari suatu barang atau jasa lalu erat hubungannya dengan keinginan pelanggan pada barang atau jasa itu. Bila tampilan dari barang atau jasa yang menjadi harapan oleh pelanggan tak cocok dengan hal nyata yang tampak, sehingga bisa kita pastikan pelanggan dapat merasakan ketidakpuasan serta bila tampilan barang atau jasa cocok ataupun lebih bagus daripada yang menjadi harapan pelanggan, sehingga kepuasan ataupun kesenangan akan segera pelanggan rasakan. Kepuasan menjadi peran yang sangat penting dalam pembelian suatu produk dan jasa yang dilakukan oleh konsumen. Menurut Lee (2010) indikator kepuasan diukur berdasarkan tiga skala pengukuran yaitu sebagai berikut: 1) Kinerja, adalah konsumen yang puas akan kinerja yang diperoleh dari produk tersebut. 2) Pengalaman yang menyenangkan, adalah konsumen yang senang memiliki pengalaman berbelanja menggunakan produk tersebut. 3) Pilihan yang tepat, adalah konsumen yang merasa menggunakan produk tersebut adalah keputusan yang tepat. 
Minat beli adalah perilaku pelanggan yang memberikan petunjuk tentang sampai beberapa jauh komitmen konsumen dalam memutuskan untuk membeli. Kebutuhan serta keinginan pelanggan terhadap perkembangan suatu produk di tahun-tahun berikutnya. Hal tersebut juga memberi pengaruh prilaku konsumen untuk melakukan membeli barang atau jasa itu. Pada istilah luar, prilaku pelanggan bisa kita sebut consumer buying behaviour ataupun consumers behaviour. Perilaku pelanggan untuk mengambil keputusan pembelian, berdasarkan atas pertimbangan produk apakah yang dapat dibeli, dimana, kapan, bagaimana, berapa jumlah, serta mengapa membeli barang atau jasa itu. Niat untuk menggunakan kembali barang atau jasa merupakan cerminan bahwa jasa yang ditawarkan perusahaan berkualitas sehingga pelanggan merasa puas. Menurut Schiffman dan Kanuk (2007:156), pembelian atau penggunaan ulang biasanya menandakan bahwa produk tersebut memenuhi persetujuan pelanggan dan pelanggan bersedia memakainya kembali.

Kepercayaan adalah dasar utama dalam sebuah usaha. Sebuah transaksi usaha diantara dua pihak ataupun lebih dapat terjadi bila masing-masing bisa percaya satu sama lain. Kepercayaan pelanggan terhadap e-commerce adalah salah satu faktor kunci melaksanakan aktivitas jual beli dengan cara online (Koufaris dan Hampton-Sosa, 2004). Berdasar kepada penjelasan tersebut, sehingga bisa dibentuk pernyataan bahwasannya kepercayaan merupakan perasaan yang muncul pada satu pihak dalam melaksanakan sebuah kewajiban yang cocok dengan yang diharapkannya. sebuah kepercayaan yang muncul pada transaksi jual beli online dapat memunculkan minat suatu individu dalam melaksanakan proses beli dengan 
cara online. Hasil penelitian yang dilaksanakan oleh Pareatama pada Prasetyo (2015) memberi bukti bahwasannya kepercayaan memberi pengaruh positif serta signifikan pada minat beli ulang. Hal itu pula berdasar dari riset yang dilaksanakan oleh Agustian (2011) memberi bukti bahwasannya kepercayaan memberi pengaruh pada minat beli ulang di ritel Indomaret di kecamatan Rambipuji. Lalu menurut Weisberg et al. (2011) juga Zboja dan Voorhees (2006) memberi pernyataan bahwasannya kepercayaan adalah faktor yang penting untuk membangun niat beli ulang. Jadi, berdasar beberapa hasil riset tersebut, peneliti membentuk hipotesis seperti berikut.

$\mathrm{H}_{1}$ : Kepercayaan pelanggan terhadap GO-FOOD positif mempengaruhi niat pembelian kembali.

Menurut Pavlou dan Fygenson (2006), kepercayaan didefinisikan sebagai keyakinan pembeli bahwa penjual akan berperilaku murah hati, cakap, dan etis. Kurangnya kepercayaan mencegah pembeli dari terlibat dalam belanja online karena mereka tidak mungkin untuk bertransaksi dengan penjual yang gagal untuk menyampaikan rasa kepercayaan, terutama karena kekhawatiran oportunisme penjual (Hoffman et al., 1999). Menurut Gefen et al. (2003), pelanggan online pada umumnya akan menghindari membeli dari penjual online yang tidak dipercaya, yang mereka anggap bahwa vendor online tersebut tidak beretika dan berperilaku dengan cara baik.

Memang, penelitian sebelumnya menunjukkan bahwa kepercayaan memainkan peran penting dalam mendorong kepuasan pelanggan (Lin dan Wang, 2006). Penelitian sebelumnya yang juga dilakukan oleh Chiou (2004) mengungkapkan bahwa kepercayaan memang memiliki pengaruh yang positif 
Bagus Dwipayana, Peran Kepuasaan Dalam Memediasi Pengaruh...

terhadap kepuasan. Begitu juga dengan penelitian yang dilakukan oleh Fang et al. (2011) yang menyatakan bahwa kepercayaan memiliki pengaruh yang positif terhadap kepuasan konsumen. Sesuai dengan penjelasan di atas maka hipotesa yang akan dibuat adalah.

$\mathrm{H}_{2}$ : Kepercayaan pelanggan terhadap GO-FOOD secara positif mempengaruhi kepuasan pelanggan.

Kepuasan adalah evaluasi pasca pembelian konsumen dan respon afektif terhadap produk atau pengalaman pelayanan secara keseluruhan (Oliver, 1992). Kepuasan dianggap sebagai prediktor kuat untuk variabel perilaku seperti niat pembelian kembali, word of mouth, atau loyalitas (Eggert, 2002). Oliver (1980) berteori bahwa kepuasan secara positif terkait dengan niat beli ulang baik secara langsung maupun tidak langsung melalui dampaknya pada sikap. Pada tahap akhir dari proses pembentukan kepuasan, kepuasan akan menentukan seberapa niat konsumen untuk menggunakan kembali produk tersebut (Tsai dan Huang, 2007).

$\mathrm{H}_{3}$ : Kepuasan pelanggan terhadap GO-FOOD secara positif mempengaruhi niat membeli ulang.

Niat beli ulang adalah bagian dari prilaku konsumsi sebuah barang atau jasa yang membikin niat beli ulang menjadi langkah kecenderungan suatu pelanggan ataupun responden yang beraksi sebelum keputusan pembelian dilakukan. Namun niat beli ulang adalah niat beli ulang barang atau jasa yang sudah dilaksanakan pada beberapa tahun yang lalu. Berdasarkan Margaretha (2008) niat beli ulang (repurchase intention), adalah proses membeli ulang yang memperlihatkan rasa ingin konsumen dalam melaksanakan proses beli ulang. Niat pembelian ulang ada saat pelanggan melaksanakan aktivitas membeli lagi untuk kedua kali ataupun 
lebih, yang mana alasan membeli ulang khususnya terpicu dari pengalaman pelanggan pada produk (Heiller, 2003). Menurut penelitian yang dilakukan oleh Fang et al. (2011) memngungkapkan bahwa kepuasan mampu memediasi pengaruh antara kepercayaan dan niat beli ulang. Begitu pula penelitian yang dilakukan oleh Rohman (2014) juga mengungkapkan bahwa kepuasan mampu memediasi pengaruh antara kepercayaan dan niat beli ulang. Oleh karena itu penulis mengasumsikan hipotesis sebagai berikut.

$\mathrm{H}_{4}$ : Kepuasan mampu memediasi pengaruh kepercayaan terhadap niat beli ulang GO-FOOD.

Sesuai dengan penjelasan hipotesis, maka dapat dibuat model konseptual yang menjelaskan secara ringkas tentang peran kepuasan dalam memediasi pengaruh antara kepercayaan terhadap niat beli ulang sebagai berikut.

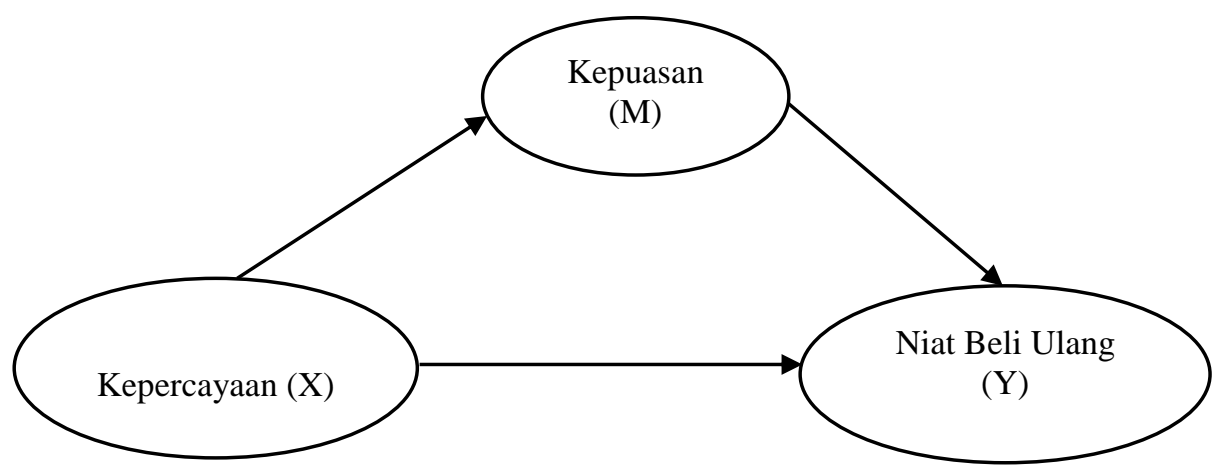

\section{Gambar 1. Kerangka Konseptual}

Sumber: Data Diolah, 2017

\section{METODE PENELITIAN}

Berdasarkan permasalahan yang diteliti di atas penelitian ini digolongkan sebagai penelitian asosiatif (hubungan), yaitu penelitian yang bertujuan untuk mengetahui hubungan dari dua variabel atau lebih (Sugiyono, 2013:5). Metode ini digunakan untuk mengetahui pengaruh antara variabel Kepercayaan, Kepuasan 
dan Niat Beli Ulang. Penelitian ini dilakukan di Fakultas Ekonomi Universitas Udayana, yang terletak di JL. PB. Sudirman, Denpasar, Bali. Lokasi ini dipilih karena terdapat beberapa masalah yang menarik untuk diteliti terutama mengenai peran kepuasan dalam memediasi pengaruh kepercayaan terhadap niat beli ulang pada GO-FOOD, serta dirasa belum ada penelitian yang dilakukan ditempat ini yang menggunakan variabel tersebut. Subyek dari penelitian ini adalah mahasiswa Fakultas Ekonomi dan Bisnis Universitas Udayana program nonreguler. Selanjutnya obyek penelitian ini ada pada bidang manajemen pemasaran yang berkaitan dengan perilaku konsumen khususnya mengenai peran kepuasan dalam memediasi pengaruh kepercayaan terhadap niat beli ulang pada GO-FOOD.

Berdasarkan pada pokok masalah yang telah dirumuskan serta hipotesis yang diajukan, maka variabel-variabel dalam penelitian ini adalah sebagai berikut: 1) Variabel eksogen (exogenous variabel) merupakan source variable atau independent variable yang tidak diprediksi oleh variabel yang lain dalam model (Hair et al., 2010:580). Variabel eksogen dari penelitian ini adalah kepercayaan (X). 2) Variabel Mediasi (M), merupakan variabel yang menghubungkan hubungan antara dua variabel. Variabel endogen mediasi dalam penelitian ini adalah Kepuasan (M). 3) Variabel endogen (endogenous variable) outcome variable ataupun dependent variable dari yang terendah suatu hubungan kausalitas pada model (Hair et al., 2010:580). Variabel endogen dalam penelitian ini adalah Niat Beli Ulang (Y).

Definisi Operasional sangat berkaitan dengan obyek penelitian yang dilakukan. Definisi operasional menyangkut segala hal yang berkaitan dengan 
bagaimana cara variabel dalam penelitian ini diukur. Berbagai indikator dalam penelitian ini adalah sebagai berikut. Kepercayaan adalah tingkat keyakinan konsumen dalam melakukan belanja khususnya dalam menggunakan GO-FOOD dengan harapan bahwa hal yang ingin dicapai konsumen tersebut dapat terpenuhi. Indikator untuk menilai kepercayaan diadopsi dari Chen dan Chang (2012): 1) Kepercayaan akan reputasi yang baik (X1), maksudnya adalah konsumen percaya bahwa GO-FOOD ini memiliki reputasi yang baik. 2) Kepercayaan mengenai keandalan kinerja (X2), maksudnya disini adalah konsumen percaya akan kinerja dari GO-FOOD dapat diandalkan. 3) Kepercayaan dalam keamanan bertransaksi (X3), maksudnya adalah konsumen percaya bahwa bertransaksi dalam GO-FOOD aman. 4) Kepercayaan sebagai bisnis yang legal (X4), maksudnya adalah konsumen percaya bahwa GO-FOOD menjalankan bisnisnya secara legal.

Variabel kepuasan pada penelitian ini adalah tingkat kesesuaian antara harapan pelanggan akan kinerja GO-FOOD dengan apa yang dirasakannya. Indikator penelitian ini diadopsi dari Lee (2010), serta disesuaikan dengan objek penelitian, sehingga persepsi tentang kepuasan diukur berdasarkan indikatorindikator sebagai berikut. 1) Kinerja (M1), adalah konsumen yang puas akan kinerja GO-FOOD. 2) Pengalaman yang menyenangkan (M2), adalah konsumen yang senang memiliki pengalaman berbelanja menggunakan GO-FOOD. 3) Pilihan yang tepat (M3), adalah konsumen yang merasa menggunakan GO-FOOD adalah keputusan yang tepat.

Variabel niat beli ulang pada penelitian ini adalah tingkat ukuran berapa besar minat pelanggan GO-FOOD untuk kembali berbelanja pada layanan tersebut 
Bagus Dwipayana, Peran Kepuasaan Dalam Memediasi Pengaruh...

lagi. Berdasarkan penelitian Chiu et al. (2009), persepsi tentang niat beli ulang diukur berdasarkan indikator-indikator sebagai berikut. 1) Adanya kesempatan (Y1), adalah kondisi konsumen memiliki kesempatan berbelanja kembali pada GO-FOOD. 2) Adanya kemungkinan (Y2), adalah kondisi konsumen memiliki kemungkinan untuk menggunakan kembali GO-FOOD. 3) Adanya niat (Y3), adalah kondisi dimana konsumen memiliki keinginan yang kuat untuk menggunakan kembali GO-FOOD.

Jenis data yang dipakai pada riset berikut ada dua yaitu data kualitatif serta data kuantitatif. Data Kualitatif, adalah data yang diberi suatu pernyataan pada bentuk kata, kalimat, dan skema (Sugiyono, 2013:13) seperti gambaran umum tentang lokasi yang diambil yaitu Fakultas Ekonomi dan Bisnis Universitas Udayana. Data Kuantitatif, yaitu data didalam bentuk angka yang bisa kita nyatakan serta dinilai menggunakan satuan hitung ataupun data kualitatif yang ditulis dalam bentuk angka (Sugiyono, 2013:13). Data kuantitatif pada riset ini yaitu hasil dari kuesioner yang akan disebarkan nantinya. Sumber primer, adalah data yang dikumpulkan langsung dari sumbernya, diamati dan dicatat pertama kali oleh peneliti. Data ini didapatkan dari hasil wawancara dan kuesioner yang akan disebarkan. Sumber sekunder, adalah data yang bukan diusahakan sendiri pengumpulannya oleh peneliti melainkan sudah dikumpulkan oleh pihak lain. Data sekunder ini berupa data jumlah pengguna internet di seluruh Indonesia.

Populasi dari penelitian adalah mahasiswa Fakultas Ekonomi dan Bisnis Universitas Udayana jurusan S1 program nonregular yang berjumlah 1873 orang. Kriteria populasi yang akan diambil adalah mahasiswa S1 yang aktif dan terdaftar 
secara resmi di Fakultas Ekonomi dan Bisnis Universitas Udayana, memiliki kartu mahasiswa Universitas Udayana, memiliki nomor induk mahasiswa, nomor induk mahasiswa, serta aktif menjadi mahasiswa sampai sekarang. Metode penentuan sampel yang dipakai dalam penelitian ini menggunakan metode probability sampling dengan Teknik random sederhana. Alasan peneliti menggunakan metode penentuan sampel ini dikarenakan jumlah populasi yang diambil dalam penelitian ini berjumlah pasti atau dapat diketahui secara pasti. Sampel yang diambil dalam penelitian ini diukur dengan menggunakan rumus Slovin, sehingga jumlah sampel yang akan diteliti sejumlah 95 sampel.

Metode pengumpulan data yang akan digunakan dalam rencana penelitian ini adalah sebagai berikut. 1) Observasi adalah metode pengumpulan data dengan cara melakukan pengamatan langsung tentang peran kepuasan dalam memediasi pengaruh kepercayaan terhadap niat beli ulang pada GO-FOOD. 2) Wawancara adalah metode pengumpulan data dengan cara melakukan Tanya jawab secara langsung dengan setiap mahasiswa Fakultas Ekonomi dan Bisnis Universitas Udayana program nonreguler jurusan S1. 3) Kuesioner adalah metode pengumpulan data dengan menggunakan daftar pertanyaan yang disebarkan kepada responden yang berkaitan dengan peran kepuasan dalam memediasi pengaruh kepercayaan terhadap niat beli ulang pada GO-FOOD. Sumber data penelitian ini adalah penarikan data primer yang menggunakan kuesioner, maka data yang diperoleh bersifat kualitatif. Skala pengukuran yang digunakan dalam penelitian ini adalah skala Likert.

Teknik analisis faktor konfirmatori ataupun Confirmatory Factor Analysis (CFA) adalah bentuk deskriptif yang tujuannya agar memberi deskripsi suatu 
Bagus Dwipayana, Peran Kepuasaan Dalam Memediasi Pengaruh...

situasi ataupun suatu ilmu dan suatu faktor menggunakan analisis yang kita hasilkan tersebut bagai measurement model dikarenakan konsep ini bisa kita gunakan menggunakan untuk ukur kuat tidaknya struktur daripada dimensinya yang dibentuk suatu faktor (Utama, 2010:177). Analisis faktor dilakukan dalam membuat penentuan apakah sekelompok variabel bisa direduksi menjadi beberapa faktor saja. Model CFA dari masing-masing variabel penelitian, adalah kepercayaan (X), kepuasan (M) serta niat beli ulang GO-FOOD pada mahasiswa Universitas Udayana (Y). pada riset berikut teknik analisis yang dipakai yaitu teknik analisis jalur (path analysis). Ghozali (2013:249) mendeflnisikan analisis jalur (path analysis) yaitu penyebaran luasnya daripada analisis regresi linear berganda saat diperkirakannya hubungan kausalitas antara yang sudah kita tetapkan berdasar pada teori. Analisis jalur dipakai dalam ditentukannya hubungan diantara tiga variable ataupun lebih saat menyetujuinya atau menolak hipotesis.

Pada riset berikut teknik analisis yang dipada yaitu teknik analisis jalur (path analysis). Ghozali (2013:249) memberi definisi analisis jalur (path analysis) yaitu perluasan daripada analisis regresi linear berganda saat membuat perkiraan hubungan kausalitas diantara yang sudah ditetapkannya berdasar pada teori. Analisis jalur dipakai sebagai penentu hubungan diantara tiga variabel ataupun lebih saat menerima atau menolak hipotesis. Dasar perhitungan koefisien jalur adalah analisis korelasi dan regresi dan dalam perhitungan menggunakan software dengan program SPSS for windows. Analisis jalur digunakan untuk menerangkan akibat langsung dan tidak langsung seperangkat variabel bebas dengan 
seperangkat variabel terikat. Riduwan dan Kuncoro (2011:152) menyebutkan langkah-langkah dalam menganalisis data dengan menggunakan path analysis adalah sebagai berikut. 1) Langkah pertama analisis jalur adalah merumuskan hipotesis dan model persamaan berdasarkan teori yang ada. 2) Membentuk diagram koefisien jalur. 3) Menghitung koefisien jalur secara simultan (keseluruhan). 4) Menghitung koefisien jalur secara individual. 5) Meringkas dan menyimpulkan.

Uji Sobel adalah metode pengujian signifikansi efek mediasi. Tes ini didasarkan pada karya Michael E. Sobel profesor statistik di Columbia University di New York, NY. Sobel, Michael E. (1986) menyatakan bahwa dalam mediasi, hubungan antara variabel independen dan variabel dependen dihipotesiskan menjadi tidak langsung, efek yang ada karena pengaruh variabel ketiga (mediator). Alhasil saat mediator termasuk dalam model analisis regresi dengan variabel bebas, pengaruh variabel independen berkurang dan efek mediator tetap signifikan.

\section{HASIL DAN PEMBAHASAN}

Uji validitas bertujuan untuk memeriksa apakah kuisioner sebagai instrument penelitian sudah tepat untuk mengukur indikator dalam penelitian. Kuesioner dapat dikatakan valid apabila pertanyaan dalam kuesioner mampu mengungkap sesuatu yang akan diukur oleh kuesioner tersebut. Instrumen pertanyaan dalam kuesioner dikatakan valid apabila koefisien korelasi $\geq 0,03$. Seluruh variabel memiliki nilai koefisien korelasi dengan skor total seluruh item pernyataan lebih besar dari 0,30. Hal ini menunjukkan bahwa butir-butir 
Bagus Dwipayana, Peran Kepuasaan Dalam Memediasi Pengaruh...

pernyataan dalam instrument penelitian tersebut valid. Reliabilitas berarti seberapa besar suatu pengukuran dapat dipercaya. Instrumen yang reliabel adalah instrumen yang bila digunakan beberapa kali untuk mengukur objek yang sama akan menghasilkan data yang sama Suatu variabel dikatakan reliabel jika memberikan nilai Cronbach alpha $(\alpha)>0,60$. Setiap variabel memiliki nilai koefisien Alpha Cronbach lebih dari 0,60. Hal ini dapat dikatakan bahwa semua variabel dalam penelitian ini adalah reliabel.

Tanggapan responden mengenai variabel kepercayaan yang berarti kepercayaan konsumen terhadap GO-FOOD tergolong sangat baik berdasarkan hasil skor rata-rata dari jawaban responden sebesar 4,39. Indikator yang memiliki rata-rata yang paling tinggi ditunjukkan pada pernyataan "Responden percaya bahwa GO-FOOD memberikan keamanan selama bertransaksi" besar nilai ratarata senilai 4,43 . Indikator yang mempunyai rata-rata skor yang terendah bila kita bandingkan dengan rata-rata skor semuanya tertunjuk di pernyataan "Responden percaya bahwa GO-FOOD mempunyai reputasi yang baik" dengan nilai rata-rata yaitu sebesar 4,35.

Tanggapan responden mengenai variabel kepuasan yang berarti kepuasan konsumen terhadap GO-FOOD tergolong sangat baik berdasarkan hasil skor ratarata dari jawaban responden sebesar 4,23. Indikator yang memiliki rata-rata yang paling tinggi ditunjukkan pada pernyataan "Responden merasa menggunakan GOFOOD adalah keputusan yang tepat" besar nilai rata-rata senilai 4,28. Indikator yang mempunyai rata-rata skor yang terendah bila kita bandingkan dengan rata- 
rata skor semuanya tertunjuk di pernyataan " Responden puas dengan kinerja GOFOOD” dengan nilai rata-rata yaitu sebesar 4,15.

Tanggapan responden mengenai variabel niat beli ulang yang berarti niat beli ulang konsumen terhadap GO-FOOD tergolong baik berdasarkan hasil skor rata-rata dari jawaban responden sebesar 4,19. Indikator yang memiliki rata-rata yang paling tinggi ditunjukkan pada pernyataan "Responden berniat untuk terus memesan makanan melalui GO-FOOD di masa depan” besar nilai rata-rata senilai 4,24. Indikator yang mempunyai rata-rata skor yang terendah bila kita bandingkan dengan rata-rata skor semuanya tertunjuk di pernyataan "Kemungkinan besar responden akan memesan GO-FOOD kembali di masa depan” dengan nilai ratarata yaitu sebesar 4,09.

Sebelum analisis jalur terlebih dahulu dilakukan analisis faktor konfirmatori agar diketahuinya bagaimana indikator-indikator setiap variabel bisa mengkonfirmasi konstruk atau variabel. Analisis faktor konfirmatori dapat membeagi indikator-indikator menjadi beberapa kelompok faktor. Bila seluruh indikasi adalah indikator konstruk jadi secara otomatis akan mengelompok membentuk beberapa faktor loading yang besar ataupun melebihi 0,5 (Ghozali, 2013:278). Komponen yang tersusun berdasarkan beberapa jenis di suatu variabel juga dapat digunakan sebagai variabel baru yang mewakili kumpulan item tersebut. Selanjutnya, variabel baru tersebut dapat digunakan untuk analisis path. Rangkuman hasil analisis faktor konfirmatori pada penelitian ini tersaji pada beberapa tabel berikut. 
Hasil uji KMO memperlihatkan semua variabel memiliki nilai $\mathrm{KMO}>0,5$, nilai signifikansi $<0,05$ dan nilai chi-square masing-masing 92,895; 81,062; dan 100,806. Hal ini menyimpulkan bahwa masing-masing variabel memiliki kecukupan sampel untuk analisis faktor. Nilai MSA masing-masing variabel lebih besar dari 0,5 . Hal ini berarti masing-masing model layak digunakan dalam analisis faktor. Nilai Percentage of Variance masing-masing variabel sudah lebih besar dari 60 persen. Hal ini berarti faktor dari masing-masing variabel memiliki kelayakan untuk menjelaskan variabel faktornya. Semua variabel memiliki loading factor di atas 0,50 atau factor loading yang tinggi. Dengan hasil ini, maka dapat dikatakan indikator-indikator pembentuk variabel Kepercayaan, Kepuasan dan Niat Beli Ulang telah menunjukkan sebagai indikator yang kuat. Selanjutnya berdasarkan analisis faktor konfirmatori ini, maka model penelitian dapat digunakan untuk analisis selanjutnya tanpa dimodifikasi atau penyesuaianpenyesuaian.

Tabel 1.

Hasil Analisis Jalur Struktur 1

\begin{tabular}{lcrr}
\hline \multicolumn{1}{c}{ Variabel } & Koefisien Regresi & t & \multicolumn{2}{c}{ Signifikansi } \\
\hline \multicolumn{1}{c}{ Kepercayaan } & 0,36 & 3,724 & 0 \\
\hline F Hitung & & & $\mathbf{1 3 , 8 6 9}$ \\
Signifikansi & & & $\mathbf{0}$ \\
R1 & & $\mathbf{0 , 1 3}$ \\
Adjusted R1 Square & & $\mathbf{0 , 1 2}$ \\
\hline
\end{tabular}

Sumber: Data Diolah, 2017

Perhitungan koefisien path dilakukan dengan analisis regresi melalui software SPSS 18.0 for Windows, diperoleh hasil yang ditunjukan pada Tabel 1 berikut. Berdasarkan hasil analisis jalur substruktur 1 seperti yang disajikan pada 
Tabel 1, maka persamaan strukturalnya adalah sebagai berikut:

$$
\begin{aligned}
& M=\beta 1 X+e_{1} \ldots \\
& M=0,360 X+e_{1}
\end{aligned}
$$

Tabel 2.

Hasil Analisis Jalur Struktur 2

\begin{tabular}{lccr}
\hline \multicolumn{1}{c}{ Variabel } & Koefisien Regresi & t & Signifikansi \\
\hline Kepercayaan & 0,235 & 2,492 & 0,015 \\
Kepuasan & 0,402 & 4,254 & 0 \\
\hline F Hitung & & & $\mathbf{1 8 , 3 5 2}$ \\
Signifikansi & & & $\mathbf{0}$ \\
$\mathbf{R}_{\mathbf{2}}$ & & & $\mathbf{0 , 2 8 5}$ \\
\hline Sumber: Data Diolah, 2017 & & &
\end{tabular}

Berdasar kepada jumlah analisis jalur substruktur 2 seperti yang terlihat di

Tabel 4.18, jadi rumus strukturalnya yaitu seperti ini:

$\mathrm{Y}=\beta 2 \mathrm{X}+\beta 3 \mathrm{M}+\mathrm{e}_{2}$

$\mathrm{Y}=0,235 \mathrm{X}+0,402 \mathrm{M}+\mathrm{e}_{2}$

Berdasar model substruktur 1 serta substruktur 2, jadi bisa kita susun model diagram jalur akhir. Didapatkan hasil pengaruh error $\left(\mathrm{Pe}_{1}\right)$ sebesar 0,933 dan pengaruh error $\left(\mathrm{Pe}_{2}\right)$ sebesar 0,845. Besar nilai determinan senilai jumlah 0,379 memiliki definisi bahwasannya senilai $37,9 \%$ varians Niat Beli Ulang dipengaruhi dari varians Kepercayaan, serta Kepuasan, namun bersisa senilai 62,1\% penjelasannya dari factor-faktor lainnya yang tak diisi di dalam model. Berdasar pada hasil analisis pengaruh Kepercayaan pada Niat Beli Ulang didapatkan besaran Sig. t senilai 0,015 dengan besaran koefisien beta 0,235 besar Sig. t 0,015 $<0,05$ berindikasi bahwasannya $\mathrm{H}_{0}$ tolak serta terima $\mathrm{H}_{1}$. Hal tersebut memiliki pengertian bahwasannya kepercayaan pelanggan pada GO-FOOD berpengaruh positif terhadap niat beli ulang. 


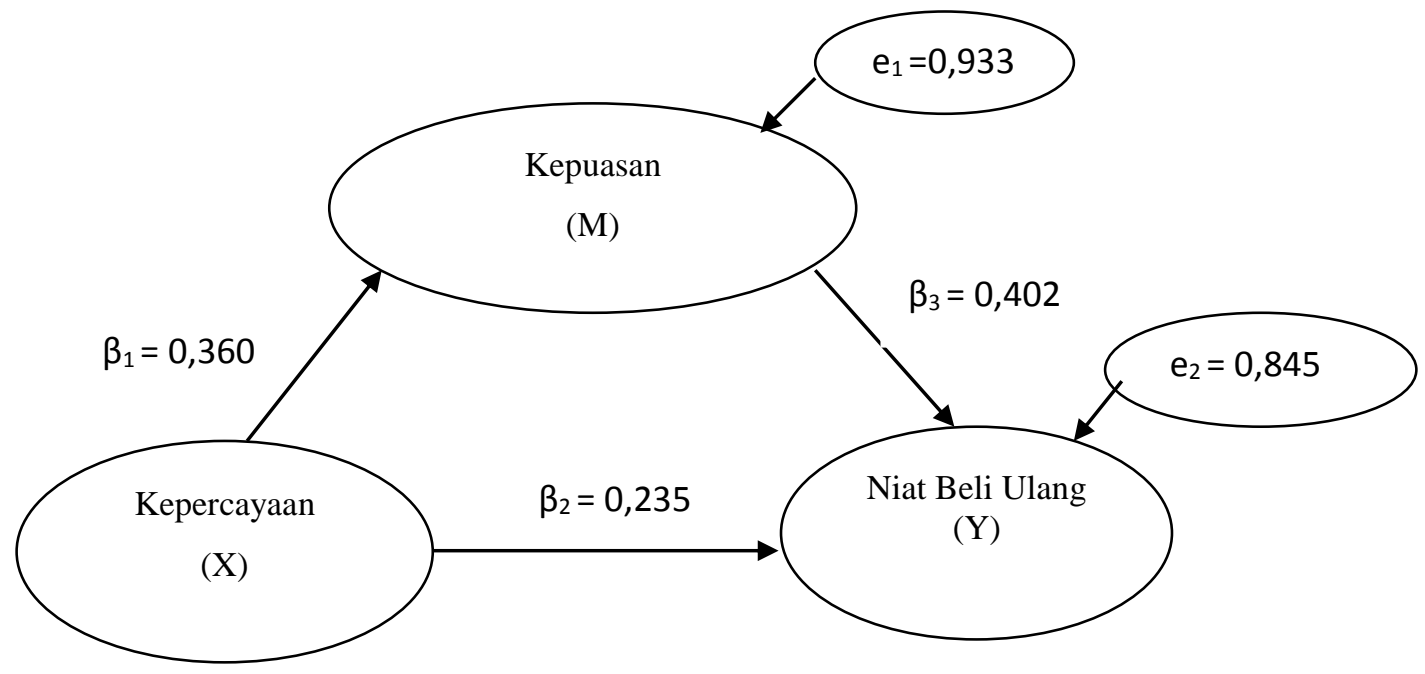

\section{Gambar 2. Validasi Model Diagram Jalur Akhir}

Sumber: Data Diolah, 2017

Berdasar hasil analisis berpengaruhnya Kepercayaan pada Kepuasan didapatkan besaran Sig. $\mathrm{t}$ senilai 0,000 dengan besaran koefisien beta 0,360. besaran Sig. t $0,000<0,05$ berindikasi bahwasannya tolak $\mathrm{H}_{0}$ serta terima $\mathrm{H}_{1}$. Hal tersebut memiliki pengertiannya bahwasannya kepercayaan pelanggan pada GOFOOD berpengaruh positif pada kepuasan. Berdasar hasil analisis berpengaruhnya Kepuasan pada Niat Beli Ulang didapatkan besaran Sig. t senilai 0,000 dengan besaran koefisien beta 0,402. Besaran Sig. $\mathrm{t} 0,000<0,05$ berindikasi bahwasannya tolak $\mathrm{H}_{0}$ serta terima $\mathrm{H}_{1}$. Hal tersebut memiliki pengertian bahwasannya kepuasan pelanggan pada GO-FOOD memiliki pengaruh positif pada niat beli ulang.

Berdasarkan diagram jalur pada Gambar 2, maka dapat dihitung besarnya pengaruh langsung dan pengaruh tidak langsung serta pengaruh total antar variabel. Sig. Tabel ANOVA menunjukkan besarnya angka probabilitas atau signifikansi pada perhitungan ANOVA. Nilai yang tertera digunakan untuk uji 
kelayanan Model Analisis (dimana sejumlah variabel x mempengaruhi variabel y) dengan ketentuan angka probabilitas yang baik untuk digunakan sebagai model regresi harus $<0,05$. Nilai ini bisa dilihat pada kolom Sig. Jika Sig. $<0,05$, maka Model Analisis dianggap layak. Jika Sig. > 0,05, maka Model Analisis dianggap tidak layak.

Tabel 3.

Hasil Uji ANOVA Struktur 1

\begin{tabular}{|c|c|c|c|c|c|c|}
\hline \multicolumn{2}{|c|}{ Model } & \multirow{2}{*}{$\begin{array}{r}\text { Sum of Squares } \\
12.199\end{array}$} & \multirow{2}{*}{$\begin{array}{r}\text { Df } \\
1\end{array}$} & \multirow{2}{*}{$\begin{array}{r}\text { Mean Square } \\
12.199\end{array}$} & \multirow{2}{*}{$\begin{array}{l}\mathrm{F} \\
13.869\end{array}$} & \multirow{2}{*}{$\begin{array}{l}\text { Sig. } \\
.000\end{array}$} \\
\hline & Regression & & & & & \\
\hline 1 & Residual & 81.801 & 93 & .880 & & \\
\hline & Total & 94.000 & 94 & & & \\
\hline
\end{tabular}

Sumber: Data Diolah, 2017

Tabel hasil uji anova struktur 1 (UJI F) di atas, diperoleh nilai kelompok pembanding $=1$, nilai dalam kelompok penyebut $=94$, pada alpha $=0,05$ maka nilai $F$ tabelnya adalah F0,05 $(1,94)=3,94$. Sedang $F_{\text {hitung }}=13,869$. Nilai $F_{\text {hitung }}>$ $\mathrm{F}_{\text {tabel }}, 13,869>3,94$, dengan nilai sig. $0,000<0,05$. Maka $\mathrm{H}_{0}$ ditolak pada taraf nyata $0,05\left(\mathrm{H}_{1}\right.$ diterima $)$.

Tabel 4.

Hasil Uji ANOVA Struktur 2

\begin{tabular}{|c|c|c|c|c|c|c|}
\hline \multicolumn{2}{|c|}{ Model } & \multirow{2}{*}{$\begin{array}{l}\text { Sum of Squares } \\
26.807\end{array}$} & \multirow{2}{*}{$\begin{array}{r}\mathrm{df} \\
2\end{array}$} & \multirow{2}{*}{$\begin{array}{l}\text { Mean Square } \\
13.404\end{array}$} & \multirow{2}{*}{$\begin{array}{c}\mathrm{F} \\
18.352\end{array}$} & \multirow{2}{*}{$\begin{array}{l}\text { Sig. } \\
.000\end{array}$} \\
\hline & Regression & & & & & \\
\hline \multirow[t]{2}{*}{1} & Residual & 67.193 & 92 & .730 & & \\
\hline & Total & 94.000 & 94 & & & \\
\hline
\end{tabular}

Sumber: Data Diolah, 2017

Kesimpulannya, pada kelompok yang diuji memiliki perbedaan yang nyata (signifikan), sehingga dapat dikatakan bahwa kepercayaan pelanggan pada GOFOOD berpengaruh secara simultan terhadap kepuasan. Tabel hasil uji anova struktur 2 (UJI F) di atas, diperoleh nilai kelompok pembanding $=2$, nilai dalam 
Bagus Dwipayana, Peran Kepuasaan Dalam Memediasi Pengaruh...

kelompok penyebut $=94$, pada alfa $=0,05$ maka nilai $\mathrm{F}$ tabelnya adalah F0,05(2,94) $=3,09$. Sedang $F_{\text {hitung }}=18,352$. Nilai $F_{\text {hitung }}>F_{\text {tabel }}, 18,352>3,09$, dengan nilai sig. $0,000<0,05$. Maka $\mathrm{H}_{0}$ ditolak pada taraf nyata $0,05\left(\mathrm{H}_{1}\right.$ diterima). Kesimpulannya, pada kelompok yang diuji memiliki perbedaan yang nyata (signifikan), sehingga dapat dikatakan bahwa Kepercayaan, dan Kepuasan berpengaruh secara simultan terhadap Niat Beli Ulang. Hasil uji Sobel menunjukkan bahwa hasil tabulasi $\mathrm{Z}=2,7603>1,96$ dengan tingkat signifikansi $0,006<0,05$ yang berarti variabel mediator yakni Kepuasan dinilai secara positif signifikan memediasi hubungan antara Kepercayaan terhadap Niat Beli Ulang.

Tujuan dari penelitian ini salah satunya adalah untuk menjelaskan pengaruh kepercayaan terhadap niat beli ulang. Berdasarkan hasil analisis pengaruh kepercayaan terhadap niat beli ulang diperoleh nilai Sig. $t$ sebesar 0,015 dengan nilai koefisien beta sebesar 0,235. Nilai Sig. t 0,015<0,05 mengindikasikan bahwa $\mathrm{H}_{0}$ ditolak dan $\mathrm{H}_{1}$ diterima. Hasil ini mempunyai arti bahwa kepercayaan berpengaruh positif terhadap niat beli ulang. Hal ini menunjukkan bahwa semakin tinggi kepercayaan pelanggan terhadap GO-FOOD maka semakin tinggi pula niat beli ulang pelanggan dalam menggunakan GO-FOOD. Berdasarkan hasil analisis pengaruh Kepercayaan terhadap Kepuasan diperoleh nilai Sig. t sebesar 0,000 dengan nilai koefisien beta 0,360 . Nilai Sig. t 0,000 $<0,05$ mengindikasikan bahwa $\mathrm{H}_{0}$ ditolak dan $\mathrm{H}_{1}$ diterima. Hasil ini mempunyai arti bahwa kepercayaan pelanggan pada GO-FOOD berpengaruh positif terhadap kepuasan. Apabila kepercayaan pelanggan semakin tinggi, maka kepuasan pelanggan akan semakin tinggi pula. 
Berdasarkan hasil analisis pengaruh Kepuasan terhadap Niat Beli Ulang diperoleh nilai Sig. $\mathrm{t}$ sebesar 0,000 dengan nilai koefisien beta 0,402. Nilai Sig. $\mathrm{t}$ $0,000<0,05$ mengindikasikan bahwa $\mathrm{H}_{0}$ ditolak dan $\mathrm{H}_{1}$ diterima. Hasil ini mempunyai arti bahwa kepuasan pelanggan pada GO-FOOD berpengaruh positif terhadap niat beli ulang. Apabila kepuasan pelanggan semakin tinggi, maka niat beli ulang akan semakin tinggi pula. Berdasarkan hasil Uji Sobel pada Tabel menunjukkan bahwa hasil tabulasi $\mathrm{Z}=2,7603>1,96$ dengan tingkat signifikansi $0,006<0,05$ yang berarti variabel mediator yakni Kepuasan dinilai secara positif signifikan memediasi hubungan antara Kepercayaan terhadap Niat Beli Ulang. Apabila tingkat kepuasan tinggi, maka kepercayaan akan semakin tinggi dan berujung pada tingginya niat beli ulang pada pelanggan.

Persaingan di industri e-commerce semakin ketat, maka dari itu dibutuhkan pemahaman mengenai bagaimana cara menumbuhkan niat pembelian ulang konsumen yang efektif dan efisien. Pemasar memerlukan informasi-informasi yang dapat mendukung proses pengambilan keputusan. Saat ini pemasar dan pengambil keputusan semakin menyadari pentingnya tingkat keefektifan dan efiensi mereka, terutama dalam rangka memenuhi kebutuhan konsumen. Keputusan yang efektif dan efisien akan memberikan efek langsung terhadap profitabilitas mereka.

Penelitian mengenai niat pembelian ulang konsumen ialah termasuk ke dalam studi perilaku konsumen. Memahami determinan niat pembelian ulang konsumen adalah salah satu kegiatan yang penting bagi setiap manajer perusahaan yang bergerak di industri e-commerce seperti GO-FOOD dari GO-JEK. Menarik pelanggan baru akan memiliki biaya yang jauh lebih mahal dibandingkan dengan 
menarik pelanggan lama untuk terus bertransaksi di aplikasi e-commerce. Hal itulah yang menjadi alasan mendasar bagaimana pentingnya niat pembelian ulang. Selain itu, penciptaan niat pembelian ulang akan mendorong terjadinya pembelian yang terus-menerus dilakukan oleh konsumen. Dengan demikian, pembelian berulang konsumen yang terus meningkat akan tercipta sebuah kekuatan bersaing bagi sebuah bisnis e-commerce.

Hasil penelitian ini menunjukkan bahwa niat pembelian ulang konsumen, terutama dalam jasa yang mereka rasakan melalui layanan GO-FOOD dipengaruhi oleh beberapa faktor. Faktor-faktor tersebut antara lain ialah kepercayaan konsumen, dan kepuasan konsumen terhadap layanan GO-FOOD yang bersangkutan. Manfaat yang mereka rasakan pada layanan GO-FOOD akan menentukan semakin kecil atau semakin tinggi tingkat kepercayaan dan kepuasan seorang konsumen yang kemudian akan mempengaruhi niat memebeli ulang dari mereka. Kepercayaan dan kepuasan yang menurun akan menciptakan pengaruh negatif terhadap terjadinya niat pembelian konsumen. Begitupun pada reputasi layanan GO-FOOD, semakin layanan GOFOOD memiliki reputasi yang baik akan menciptakan sebuah nilai tambah dalam kepercayaan dan kepuasan konsumen kepada layanan GO-FOOD tersebut.

\section{SIMPULAN DAN SARAN}

Berdasarkan hasil penelitian tentang analisis pengaruh kepercayaan dan kepuasan terhadap niat beli ulang dapat disimpulkan bahwa. 1) Variabel kepercayaan berpengaruh positif signifikan terhadap niat beli ulang, artinya kepercayaan membantu niat beli ulang dalam menggunakan jasa GO-FOOD. 2) Variabel kepercayaan berpengaruh positif signifikan terhadap kepuasan, artinya 
kepercayaan dapat menimbulkan rasa puas pada konsumen GO-FOOD. 3) Variabel Kepuasan berpengaruh positif signifikan terhadap niat beli ulang, artinya kepuasan membantu niat beli ulang, karena konsumen akan memilih untuk melakukan pembelian ulang sesuai dengan kepuasan yang dirasa oleh konsimen. 4) Variabel kepuasan memediasi pengaruh kepercayaan terhadap niat beli ulang secara positif.

Berdasarkan kesimpulan yang didapat, adapun sarn yang dapat diberikan baik kepada pihak manajemen GO-FOOD ataupun peneliti selanjutnya, yaitu. 1) Berdasarkan hasil penelitian, tingginya tingkat kepercayaan dan kepuasan konsumen akan meningkatkan peluang niat membeli ulang dari konsumen. Oleh karena itu, pihak manajemen atau pemasaran GO-FOOD harus mempertahankan atau bahkan meningkatkan kualitas pelayanan dari produk layanan yang ditawarkan agar dapat mempertahankan citra perusahaan atau jasa yang ditawarkan, sehingga dapat menumbuhkan niat memebeli ulang dari konsumen, yang kemudian akan meningkatkan profitabilitas perusahaan. 2) Berdasarkan hasil penelitian, variabel kepercayaan dan kepuasan dapat mempengaruhi niat beli ulang sebesar $37,9 \%$, sedangkan sisanya $62,1 \%$ disebabkan oleh faktor-faktor lain yang tidak terdapat pada penelitian ini.

\section{REFERENSI}

A. Eggert, W. Ulaga. 2002. Customer perceived value: a substitute for satisfaction in business markets. Journal of Business \& Industrial Marketing. 17(2-3), pp: 107-118.

Agustian, Trio. 2011. Pengaruh dimensi variabel relationship marketing terhadap kepercayaan konsumen dan minat pembeli ulang pada ritel indomaret di kecamatan rambipuji. Skripsi sarjana jurusan Manajemen pada Fakultas Ekonomi Universitas Jember, Jember. 
Ajzen, I. 1991. The theory of planned behavior. Organizational Behavior and Human Decision Processes, 50 (2), pp: 179-211.

APJII dan PusKaKom. 2015. Survei pengguna internet tahun 2015. Jakarta.

Assauri, Sofjan. 2011. Manajemen Pemasaran, Konsep Dasar dan Strategi. Jakarta: PT Rajagrafindo Persada.

Ba, S., \& Pavlou, P. A. 2002. Evidence of the effect of trust building technology in electronic markets: Price premiums and buyer behavior. MIS quarterly, 26 (3), pp: 243-268.

Baron, R. M., \& Kenny, D. A. 1986. The moderator-mediator variable distinction in social psychological research: Conceptual, strategic, and statistical considerations. Journal of personality and social psychology, 51 (6), pp 1173-1182.

Baskara, Isnain Putra, dan Guruh Taufan Hariyadi. 2014. Analisis Pengaruh Kepercayaan, Keamanan, Kualitas Pelayanan dan Persepsi akan Resiko Terhadap Keputusan Pembelian Melalui Situs Jejaring Sosial (Studi Pada Mahasiswa di Kota Semarang). Skripsi Sarjana jurusan Manajemen pada Fakultas Ekonomi dan Bisnis Universitas Dian Nuswantoro, Semarang.

Bhattacherjee, A. 2001. An Empirical Analysis of the Antecedents of Electronic Commerce Service Continuance. Decision Support Systems, 32 (2), pp: 201-214.

Chen, Yu-Shan dan Ching-Hsun Chang. 2012. Enhance Green Purchase Intentions-The Role of Green Perceived Value, Green Perceived risk, and Green Trust. Management Research News, 50 (3), pp: 502-520.

Chiou, J.S. 2004. The antecedents of consumers' loyalty toward Internet service providers. Information \& Management, 41(6), pp: 685-695.

Chiu, C. M., Chang, C. C., Cheng, H. L., dan Fang, Y. H. 2009. Determinants of customer repurchase intention in online shopping. Online information review, 33 (4), pp: 761-784.

Dolatabadi, H.R., and Ebrahimi, H. 2010, Factors influencing Iranian consumers trust in Internet shopping, European Journal of Social Sciences, 16 (2), pp: 307-318.

Eggert, A. 2006. Intangibility and perceived risk in online environments. Journal of Marketing Management, 22 (5-6), pp: 553-572. 
Fang, Y.H., Chao-Min Chiu and Eric T.G. Wang. 2011. Understanding customers' satisfaction and repurchase intentions: An integration of IS success model, trust, and justice. Internet research, 21 (4), pp: 473-503.

Gefen, D., and Straub, D.W. 2004, Consumer trust in b2c e-commerce and the importance of social presence: Experiment in e-products and e-services, International Journal of Management Science, 36 (6), pp: 407-424.

Gefen, D., Karahanna, E. \& Straub, D.W. 2003. Trust and TAM in online shopping: an integrated model. MIS Quarterly, 27 (1), pp: 51-90.

Ghozali, Imam. 2013. Aplikasi Analisis Multivariate dengan Program IBM SPSS 2.1, Edisi. Ketujuh, Semarang: Badan Penerbit UNDIP.

Go-Jek Indonesia. 2016. Kata Mereka Para Pengguna Go-Food. https://www.gofood.co.id/journals/show/top-spenders. Diakses tanggal 20, bulan 11, tahun 2016.

Go-Jek Indonesia. 2016. Ulasan Singkat Mengenai Go-Food. https://www.gofood.co.id/. Diakses tanggal 20, bulan 11, tahun 2016.

Go-Jek Indonesia. 2016. Ulasan Singkat Mengenai Go-Jek. https://www.gojek.com/. Diakses tanggal 20, bulan 11, tahun 2016.

Hellier, Kotler, P., Geursen, G.M., Carr, R.A., \& Rickard, J.A. 2003. Customer Repurchase Intention: A General Structural Equation Model. European Journal of Marketing, 37 (11), pp: 1762-1800.

Hoffman, D.L., Novak, T.P. \& Perlta, M. 1999. Building consumer trust online. Communications of the ACM, 42 (4), pp: 50-56.

Husein Umar, 2007. Metode Penelitian Untuk Skripsi Dan Tesis Bisnis. Jakarta: PT. Raja Grafindo Persada.

Jarvenpaa, S.L., Tractinsky, J., and Vitale, M. 2000, Consumer trust in an Internet store, Information Technology and Management, 1 (1 \& 2), pp: 45-71.

Kaur, G., and Khanam Quareshi, T. 2015. Factors obstructing intentions to trust and purchase products online. Asia Pacific Journal of Marketing and Logistics, 27 (5), pp: 758-783.

Kotler dan Keller, 2009. Manajemen Pemasaran Edisi 13 Jilid 1. Jakarta: PT Indeks.

Kotler, Philip. 2008. Manajemen Pemasaran Jilid I. Jakarta: PT Indeks Kelompok Gramedia. 
Kottler, P. 2000. Marketing Management, Prentice Hall. Englewood Cliff. NJ.

Koufaris, M., \& Hampton-Sosa, W. 2004. The development of initial trust in an online company by new customers. Information \& management, 41 (3), pp: 377-397.

Laudon, K.C., dan Laudon, J.P., 2000. Management Information Systems: Organization and Technology in the Networked Enterprise. Sixth Edition. Prentice-Hall International, Inc. New Jersey.

Lee, M. C. 2010. Explaining and Predicting Users' Continuance Intention Toward E-Learning: An Extension of The Expectation-Confirmation Model. Computers \& Education, 54 (2), pp: 506-516.

Lin, H.H. \& Wang, Y.S. 2006. An examination of the determinants of customer loyalty in mobile commerce contexts. Information \& Management, 43 (3), pp: 271-282.

Ling, K. C., bin Daud, D., Piew, T. H., Keoy, K. H., \& Hassan, P. 2011. Perceived risk, perceived technology, online trust for the online purchase intention in Malaysia. International Journal of Business and Management, 6(6), pp: 167-182.

Margaretha, Ardhanari. 2008. Customer Satisfication Pengaruhnya Terhadap Brand Preference dan Repurchase Intention Private Brand. Jurnal Riset Ekonomi dan Bisnis, 8 (2) pp: 58-68.

Martin, D., Consuegra, Molina, A., and Esteban, A. 2007. An Integrated Model of Price, Satisfaction and Loyalty: An Empirical Analysis in the Service Sector. Journal of Product and Brand Management, 16 (7), pp: 459-468.

Mayer, R.C., Davis, J.H., and Schoorman, F.D. 1995, An integrative model of organisational trust, Academy of Management Review, 20 (3), pp: 709-734.

McKnight, D.H., Choudhury, V., and Kacmar, C. 2002, Developing and validating trust measures for e-commerce: An integrative topology, Journal of Information Systems Research, 13 (3), pp: 334-359.

Meskaran, fatemen, Zuraini Ismail, dan Bharani Shanmugam. 2013. Online Purchase Intention: Effects of Trust and Security Perception. Australian Journal of Basic and Applied Sciences, 7 (6), pp: 307-315.

Murwatiningsih, dan E.P. Apriliani. 2013. Pengaruh Risiko Dan Harga Terhadap Keputusan Pembelian Melalui Kepercayaan Konsumen. Jurnal Dinamika Manajemen, 4 (2), pp: 184-191. 
Muslikhah, Siti, RR., Yuni Astuti dan Mahyudin. 2015. Pengaruh kepuasan konsumen dan kepercayaan merek pada niat berkunjung kembali hotel di Yogyakarta. Jurnal Manajemen, 5 (1), hal: 68-78.

Ngazis, Amal Nur dan Mitra Angelia. 2016. Survei: Go-Jek Ungguli Grab. http://teknologi.news.viva.co.id/news/read/748464-survei-gojek-ungguligrab. Diakses tanggal 10, bulan 11, tahun 2016.

Oliver, R.L. 1980. A cognitive model for the antecedents and consequences of satisfaction. Journal of Marketing Research. 17 (4), pp: 460-469.

Pavlou, P. 2001. Integrating trust in electronic commerce with the technology acceptance model: model development and validation. Amcis 2001 proceedings, pp: 816-822.

Pavlou, P. A., and Gefen, D. 2004. Building effective online marketplaces with institution-based trust. Information systems research, 15 (1), pp: 37-59.

Pavlou, P.A., and Fygenson, M. 2006, Understanding and predicting electronic commerce adoption: An extension of the theory of planned behaviour, Management Information Systems Quarterly, 30 (1), pp: 115-143.

Pleshko, Lary P. dan Samar M. Baqer. 2008. A Path Analysis Study of The Relationship Among Consumer Satisfaction, Loyalty, and Market Share in Retail Service. Academy of Marketing Studies Journal, 12 (2), pp: 111127.

Prasetyo, S. A., dan Widiyanto, I. 2015. Analisis faktor-faktor yang mempengaruhi kepercayaan serta dampaknya terhadap minat beli ulang (Studi Kasus Pada Pengguna Situs OLX. co. id di Pulau Jawa). Skripsi Sarjana jurusan Manajemen pada Fakultas Ekonomika dan Bisnis Universitas Diponegoro, Semarang.

Pratomo, Aditya. 2015. "Bola Salju" Ojek Online Terus Bergulir. http://sentananews.com/news/news/bola-salju-ojek-online-terus-bergulir12239. Diakses tanggal 16, bulan 11, tahun 2016.

Preacher, Kristopher J., dan Andrew F. Hayes. 2004. SPSS and SAS Procedures for Estimating Indirect Effects ini Simple Mediation Models, Behavior Research Methods, Instruments \& Computers, 36 (4), pp: 717-731.

R.L. Oliver. 1992. An investigation of the attribute basis of emotion and related affects in consumption: suggestions for a stagespecific satisfaction framework, in: J. Sherry, B. Sternthal (Eds.). Advance in Consumer Research, 19, pp: 237-244. 
Rahardjo, B. 2002. Keamanan Sistem Informasi Berbasis Internet. Bandung: PT Insan Komunikasi Indonesia.

Rahayu, Deasy, Srikandi Kumadji dan Andriani Kusumawati. 2016. Experiental marketing dan pengaruhnya terhadap kepuasan pelanggan dan minat pembelian ulang (repurchase intention): survei pada pelanggan warung coto abdullah daeng sirua, kota makassar, Jurnal Administrasi Bisnis (JAB), 35 (2), hal: 197-203.

Riduwan dan Engkos Achmad Kuncoro. 2011. Cara Menggunakan dan Memaknai Analisis Jalur (Path Analysis). Bandung: Alfabeta.

Riduwan dan Sunarto. 2012. Pengantar Statistika Untuk Penelitian Pendidikan, Sosial, Ekonomi dan Bisnis. Bandung: Alfabeta.

Rochman, Nur Ahmad. 2014. Pengaruh Kualitas Layanan, Nilai Produk dan Kepercayaan Terhadap Niat Untuk Bertransaksi Ulang Dengan Kepuasan Anggota Sebagai Mediasi Pada Kospin "Jasa" Cabang Batang. Skripsi sarjana jurusan Manajemen pada Fakultas Ekonomi dan Bisnis Universitas Stikubank, Semarang.

Schiffman, L., \& Kanuk, L. L. 2008. Perilaku konsumen. Jakarta: Indeks.

Sobel, Michael E. 1986. Some New Result on Indirect Effects and Their Standard Errors in Covariance Structure. Sociological Methodology, 16 (), pp: 159186.

Sugiyono. 2013. Metode Penelitian Bisnis. Bandung: Alfabeta.

Tsai, H.T. and Huang, H.C. 2007. Determinants of e-repurchase intentions: an integrative model of quadruple retention drivers. Information \& Management, 44 (3), pp: 231-239.

Utama, Made Suyana. 2010. Aplikasi Analisis Kuantitatif. Denpasar: Sastra Utama.

Utami, Chr, Whidya. 2006. Relationship Effort dan Kualitas Layanan sebagai Strategi Penguat Relationship Outcomes. Jurnal Manajemen Pemasaran, 1(1), hal: 23-34.

Weisberg, J., Te'eni, D. dan Arman, L. 2011. Past purchase and intention to purchase in e-commerce: the mediation of social presence and trust. Internet Research, 21 (1), pp: 82-96. 
E-Jurnal Manajemen Unud, Vol. 7, No. 10, 2018: 5197-5229

Wikipedia Indonesia. 2016. Definisi Perusahaan Rintisan (Start-up). https://id.wikipedia.org/wiki/Perusahaan_rintisan/. Diakses tanggal 20, bulan 11, tahun 2016.

Wirawan, Nata. 2014. Cara Mudah Memahami Statistika Ekonomi dan Bisnis. Denpasar: Keraras Emas.

Yulianti, Ni Made Dhian Rani, Ni Wayan Sri Suprapti dan Ni Nyoman Kerti Yasa. 2014. Pengaruh Citra Toko Terhadap Kepuasan Pelanggan Dan Niat Beli Ulang Pada Circle K di Kota Denpasar, Jurnal Manajemen Strategi Bisnis dan Kewirausahaan, 8 (1), hal: 36-44.

Yunitasari, H., \& Yuniawan, A. 2006. Analisis Pengaruh Kesadaran Merek, Persepsi Kualitas dan Loyalitas Merek Terhadap Nilai Pelanggan Mobil Merek Toyota. Studi manajemen dan organisasi, 3 (2), hal: 15-28.

Zboja, J.J. and Voorhees, C.M. 2006. An empirical examination of the impact of brand trust and satisfaction on retailer repurchase intentions. Journal of Services Marketing, 20 (5), pp: 381-390. 